\title{
Standards for $\mathrm{pH}$ Measurements of Bis-[(2-Hydroxyethyl)amino]acetic Acid (BICINE) from (278.15 to 328.15) K
}

\author{
Rabindra N. Roy ${ }^{*}$, Lakshmi N. Roy, Blake M. Bodendorfer, Zachary M. Downs, Alexis L. Jenkins \\ and Isaac B. Henson
}

Hoffman Department of Chemistry, Drury University, 900 N. Benton Ave., Springfield, Missouri 65802, USA

\begin{abstract}
The second dissociation constant, $\mathrm{p} K_{2}$, and related thermodynamic data for BICINE have been previously determined and reported from temperatures (278.15 to 328.15$) \mathrm{K}$. For the present study, three buffer solutions without $\mathrm{NaCl}$, and five with $\mathrm{NaCl}$ yielding an ionic strength $\left(I=0.16 \mathrm{~mol} \cdot \mathrm{kg}^{-1}\right)$ similar to that of blood plasma were prepared. These buffer solutions have been evaluated in the temperature range of (278.15 to 328.15$) \mathrm{K}$ using the extended form of the Debye-Hückel equation. The Bates-Guggenheim convention is only valid when $I \leq 0.1 \mathrm{~mol} \cdot \mathrm{kg}^{-1}$. Values of the residual liquid junction potential $\left(\delta E_{\mathrm{j}}\right)$ between the BICINE solutions and the saturated $\mathrm{KCl}$ calomel electrode have been estimated at (298.15 and 310.15) K. Two BICINE buffer solutions are recommended as primary standard reference solutions for $\mathrm{pH}$ measurements of biological fluids.
\end{abstract}

Keywords: Buffer, Zwitterionic, BICINE, pH, Emf.

\section{INTRODUCTION}

Good et al. [1, 2] have recommended a set of zwitterionic amino acid buffers for the investigation of physiological solutions across a broad $\mathrm{pH}$ range.The second dissociation constant $\left(\mathrm{p} K_{2}\right)$ of the zwitterionic buffer BICINE has recently been published [3]. Standard $\mathrm{pH}$ values of six buffer solutions of BICINE and NaBICINE without $\mathrm{NaCl}$ in the ionic strength range $I=0.02$ to $0.08 \mathrm{~mol} \cdot \mathrm{kg}^{-1}$ and four buffer solutions in isotonic saline media of $I=0.16 \mathrm{~mol} \cdot \mathrm{kg}^{-1}$ with $\mathrm{NaCl}$ from (278.15 to 328.15$) \mathrm{K}$ have been reported earlier from this laboratory [3]. The $\mathrm{pH}$ values at these temperatures particularly at (298.15 and 310.15$) \mathrm{K}$ in a wide variety of buffer solutions differing in buffer ratios and specific concentrations of BICINE and NaBICINE are highly significant for biomedical research and other clinical media. In previously published research, the buffer ratios of BICINE and NaBICINE without the presence of $\mathrm{Cl}^{-}$are 1:1; whereas, for buffer solutions containing $\mathrm{Cl}^{-}$with $I=0.16 \mathrm{~mol} \cdot \mathrm{kg}^{-1}$ they primarily are $1: 1,2: 1$, and $4: 1$. But there is a gap of $\mathrm{pH}$ data for some important concentrations and buffer ratios. The purpose, meaning and justification of this present investigation are clearly stated below.

In order to establish a 'universal' $\mathrm{pH}$ scale for $\mathrm{pH}$ measurements of blood plasma and other clinical samples, there is a strong need for reliable $\mathrm{pH}$ values of the same buffer, but different buffer concentrations and buffer ratios so that the $\mathrm{pH}$ values would lie within the physiological region of $\mathrm{pH} 6$ - 8. Thus the investigation of BICINE buffer of some

*Address correspondence to this author at the Hoffman Department of Chemistry, Drury University, 900 N. Benton Ave., Springfield, Missouri 65802, USA; Tel: 417-873-7247; Fax: 417-873-7856;

E-mail: rroy@drury.edu additional and entirely new buffer ratios and concentrations are essential for filling this missing gap in the establishment of a self-consistent $\mathrm{pH}$ scale for physiological application. Thus the authors have conducted this study with a view to providing accurate $\mathrm{pH}$ data for eight (three without $\mathrm{NaCl}$ and five with $\mathrm{NaCl}$ ) completely new buffer ratios and buffer concentrations of BICINE and NaBICINE. The results are highly satisfactory. Now the combined reliable $\mathrm{pH}$ results of ten buffer solutions from previous publications [3] and eight buffer solutions from the present study would complete the missing gap and significantly advance the $\mathrm{pH}$ database for the establishment of a 'universal' pH scale.

The zwitterionic buffer HEPBS [4] has been recommended as a secondary standard in the $\mathrm{pH}$ range 7 to 8 for clinical research. The goal of the current investigation is to provide reliable and accurate $\mathrm{pH}$ values for the $\mathrm{N}$ - substituted amino acid buffer BICINE, the structure of which is given in Fig. (1).

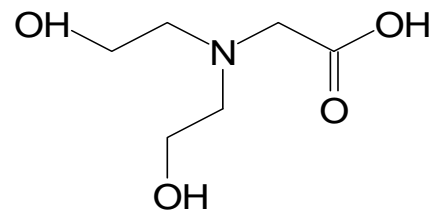

Fig. (1). [bis(2-hydroxyethyl)amino]acetic acid (BICINE).

BICINE, as well as other zwitterionic buffers, may be used as $\mathrm{pH}$ standard physiological buffers for biomedical research, protein chemistry, and clinical fluids. The currently used NIST certified physiological phosphate primary standard buffer has recorded $\mathrm{pH}$ values of 7.415 and 7.395 at (298.15 and 310.15$) \mathrm{K}$, respectively $[5,6]$. This phosphate buffer consists of $0.008695 \mathrm{~mol} \cdot \mathrm{kg}^{-1} \mathrm{KH}_{2} \mathrm{PO}_{4}$ and 0.03043 
$\mathrm{mol} \cdot \mathrm{kg}^{-1} \mathrm{Na}_{2} \mathrm{HPO}_{4}$. There are problems associated with the widely used phosphate buffer. Some of these disadvantages have been previously explained $[4,7,8]$. The potential for complex formation with cations, such as $\mathrm{Mg}^{+2}$ and $\mathrm{Ca}^{+2}$, does exist with use of phosphate buffer. However, the likeliness of such an occurrence for BICINE buffer has been minimized with a high $\mathrm{NaCl}$ concentration giving an isotonic saline solution of $I=0.16 \mathrm{~mol} \cdot \mathrm{kg}^{-1}$. The physiological buffer BICINE is highly compatible with blood and other biological media. Based on experiments [13], this buffer has negligible interference with $\mathrm{Ca}^{+2}, \mathrm{Mg}^{+2}$, etc. of blood ingredients.

$\mathrm{Wu}$ and associates $[7,8]$ have published $\mathrm{pH}$ and $\mathrm{p} K_{2}$ values for $N$-(2-hydroxyethyl)piperazine- $N$ '-2-ethanesulfonic acid, HEPES; and MOPSO. Roy et al. [9] reported $\mathrm{p} K_{2}$ and $\mathrm{pH}$ values of $\mathrm{N}$-substituted aminopropane sulfonic acid DIPSO buffer. These solutions are useful for $\mathrm{pH}$ control in the physiological region close to that of blood serum.

The following compositions were examined for the determination of $\mathrm{pH}(\mathrm{s})$ values:(a) BICINE (0.02) + NaBICINE (0.02), (b) BICINE (0.04) + NaBICINE (0.08), (c) BICINE $(0.06)+$ NaBICINE $(0.06)$, (d) BICINE $(0.02)+$ NaBICINE $(0.02)+\mathrm{NaCl}(0.14)$, (e) BICINE (0.04) + NaBICINE(0.04) $+\mathrm{NaCl}(0.12)$, (f) BICINE (0.05) + NaBICINE $(0.05)+$ $\mathrm{NaCl}(0.11)$, (g) BICINE $(0.06)+\mathrm{NaBICINE}(0.06)+\mathrm{NaCl}$ (0.10), (h) BICINE (0.09) + NaBICINE (0.03) + $\mathrm{NaCl}(0.13)$.

\section{EXPERIMENTAL}

The BICINE was obtained from Sigma Chemical Company. After recrystallization two times from $75 \%$ ethanol, an assay of $99.96 \%$ with a standard deviation of $0.04 \%$ was obtained by titration of BICINE with the standard $\mathrm{NaOH}$ solution. The detailed procedure has been previously reported in the literature [10]. Buffer solutions from (a) to (h), as mentioned above, were prepared from mass methods by weighing solid BICINE buffer, ACS reagent grade and re- crystallized $\mathrm{NaCl}$, a standard $\mathrm{NaOH}$ solution (for the preparation of NaBICINE), and carefully calculated amounts of double distilled $\mathrm{CO}_{2}$-free water. Buoyancy corrections were made for all masses used in buffer solution preparation.

The cell design, preparation procedures of the hydrogen electrode using chloroplatinic acid, hydrogen gas purification, silver-silver chloride electrode of the thermal electrolytic type, solution preparation, voltmeter and other experimental details have been described previously $[9,11,12]$.

\section{METHODS AND RESULTS}

The emf (electromotive force) values needed for the $\mathrm{pH}(\mathrm{s})$ calculations are given in Tables $\mathbf{1}$ and $\mathbf{2}$ for the following cell (A) containing three solutions without $\mathrm{NaCl}$ and five solutions with $\mathrm{NaCl}$ to give them an ionic strength of $I=$ $0.16 \mathrm{~mol} \cdot \mathrm{kg}^{-1}$. The emf values have been corrected to a hydrogen pressure of $101.325 \mathrm{kPa}$. At $T=298.15 \mathrm{~K}$ the uncertainties of emf, on the average, lie within $0.02 \mathrm{mV}$ in all experimental temperatures.

The method of Bates $[5,10]$ has been used to evaluate the conventional standard $\mathrm{pH}$ values for buffer solutions (a) to $(\mathrm{h})$ as was done previously $[12,13,14]$. The following cell (A) is used for the collection of cell potential data:

$\operatorname{Pt}(s), \mathrm{H}_{2}(g), 101.325 \mathrm{kPa} \mid \operatorname{BICINE}\left(m_{1}\right)+\operatorname{NaBICINE}\left(m_{2}\right)+$ $\mathrm{NaCl}\left(m_{3}\right) \mid \operatorname{AgCl}(s), \operatorname{Ag}(s)(\mathrm{A})$

where the molalities of the respective species are indicated inside the bracket.

The cell (B) is the flowing junction cell. It was used for the evaluation of the liquid junction potential at the contact point between the buffer solution and the heavier, saturated $\mathrm{KCl}$ solution shown with a double vertical line below:

$\operatorname{Pt}(s), \mathrm{H}_{2}(g), 101.325 \mathrm{kPa} \mid \operatorname{BICINE}\left(m_{1}\right)+\operatorname{NaBICINE}\left(m_{2}\right)+$ $\mathrm{NaCl}\left(m_{3}\right) \| \mathrm{KCl}(\mathrm{satd}), \mathrm{Hg}_{2} \mathrm{Cl}_{2}(s), \mathrm{Hg}(l)$

Table 1. Cell Potential of Cell A (in Volts): Pt(s); $\mathrm{H}_{2}(\mathrm{~g}), 101.325 \mathrm{kPa}\left|\mathrm{BICINE}\left(m_{1}\right), \operatorname{NaBICINE}\left(m_{2}\right), \mathrm{NaCl}\left(m_{3}\right)\right| \operatorname{AgCl}(\mathrm{s}), \operatorname{Ag}(\mathrm{s})$

\begin{tabular}{|c|c|c|c|c|c|c|c|c|c|c|c|c|c|c|}
\hline$m_{1}$ & $m_{2}$ & $m_{3}$ & \multicolumn{12}{|c|}{$T / \mathbf{K}$} \\
\hline \multicolumn{3}{|c|}{$\mathrm{mol} \cdot \mathbf{k g}^{-1}$} & 278.15 & $283.15 \mathrm{~K}$ & 288.15 & 293.15 & 298.15 & 303.15 & 308.15 & 310.15 & 313.15 & 318.15 & 323.15 & 328.15 \\
\hline 0.02 & 0.04 & 0.005 & 0.83782 & 0.84079 & 0.84330 & 0.84598 & 0.84855 & 0.85098 & 0.85355 & 0.85469 & 0.85630 & 0.85863 & 0.86107 & 0.86339 \\
\hline 0.02 & 0.04 & 0.010 & 0.82183 & 0.82467 & 0.82692 & 0.82931 & 0.83163 & 0.83383 & 0.83625 & 0.83743 & 0.83869 & 0.84079 & 0.84278 & 0.84466 \\
\hline 0.02 & 0.04 & 0.015 & 0.81254 & 0.81528 & 0.81744 & 0.81960 & 0.82185 & 0.82388 & 0.82626 & 0.82752 & 0.82850 & 0.83050 & 0.83215 & 0.83368 \\
\hline 0.02 & 0.04 & 0.020 & 0.80636 & 0.80905 & 0.81095 & 0.81315 & 0.81543 & 0.81735 & 0.81970 & 0.82093 & 0.82178 & 0.82366 & 0.82513 & 0.82636 \\
\hline 0.04 & 0.08 & 0.005 & 0.83546 & 0.83844 & 0.84115 & 0.84370 & 0.84629 & 0.84867 & 0.85096 & 0.85174 & 0.85304 & 0.85492 & 0.85673 & 0.85904 \\
\hline 0.04 & 0.08 & 0.010 & 0.82056 & 0.82349 & 0.82583 & 0.82821 & 0.83056 & 0.83273 & 0.83498 & 0.83569 & 0.83693 & 0.82858 & 0.84033 & 0.84344 \\
\hline 0.04 & 0.08 & 0.015 & 0.81215 & 0.81486 & 0.81683 & 0.81914 & 0.82140 & 0.82349 & 0.82577 & 0.82644 & 0.82786 & 0.82944 & 0.83100 & 0.83509 \\
\hline 0.04 & 0.08 & 0.020 & 0.80643 & 0.80918 & 0.81120 & 0.81348 & 0.81570 & 0.81752 & 0.81994 & 0.82078 & 0.82202 & 0.82354 & 0.82537 & 0.83035 \\
\hline 0.06 & 0.06 & 0.005 & 0.82756 & 0.83068 & 0.83355 & 0.83623 & 0.83882 & 0.84122 & 0.84345 & 0.84408 & 0.84544 & 0.84726 & 0.84877 & 0.85011 \\
\hline 0.06 & 0.06 & 0.010 & 0.81166 & 0.81442 & 0.81698 & 0.81928 & 0.82158 & 0.82377 & 0.82573 & 0.82619 & 0.82748 & 0.82905 & 0.83042 & 0.83143 \\
\hline 0.06 & 0.06 & 0.015 & 0.80230 & 0.80490 & 0.80725 & 0.80929 & 0.81148 & 0.81351 & 0.81532 & 0.81568 & 0.81694 & 0.81844 & 0.81971 & 0.82046 \\
\hline 0.06 & 0.06 & 0.020 & 0.79604 & 0.79848 & 0.80074 & 0.80247 & 0.80469 & 0.80663 & 0.80838 & 0.80848 & 0.80991 & 0.81139 & 0.81263 & 0.81315 \\
\hline
\end{tabular}


Table 2. Cell Potential of Cell A (in Volts): Pt(s); $\mathrm{H}_{2}(\mathrm{~g}), 101.325 \mathrm{kPa}\left|\mathrm{BICINE}\left(m_{1}\right), \mathrm{NaBICINE}\left(\mathrm{m}_{2}\right), \mathrm{NaCl}\left(m_{3}\right)\right| \operatorname{AgCl}(\mathrm{s}), \operatorname{Ag}(\mathrm{s})$

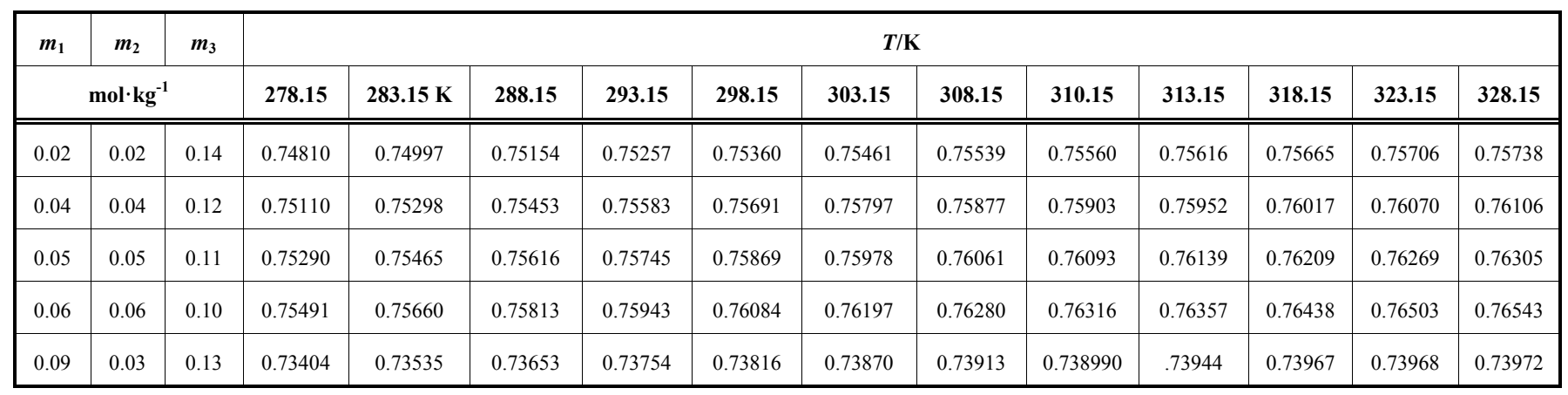

where the symbols "s," "l," and " $g$ " imply the solid, liquid, and gaseous states.

In routine laboratory $\mathrm{pH}$ measurements, a glass electrode of the $\mathrm{pH}$ meter commonly replaces the hydrogen electrode. For cell (B), the values of the standard electrode potential, denoted as $E_{S C E}^{\circ}$, of the saturated calomel electrode were taken as -0.2415 and $-0.2335 \mathrm{~V}$ at $(298.15$ and 310.15$) \mathrm{K}$ $[14,15]$, respectively.

For cell (C), the phosphate salts were universally used NIST standard reference solutions. The cell diagram for cell (C) is as follows:

$\mathrm{Pt}(s), \mathrm{H}_{2}(g), 101.325 \mathrm{kPa} \mid \mathrm{KH}_{2} \mathrm{PO}_{4}\left(m_{1}\right)+\mathrm{Na}_{2} \mathrm{HPO}_{4}\left(m_{2}\right) \|$ $\mathrm{KCl}\left(\right.$ satd), $\mathrm{Hg}_{2} \mathrm{Cl}_{2}(s), \mathrm{Hg}(l)$

where $m_{1}=0.008695$, and $m_{2}=\mathrm{Na}_{2} \mathrm{HPO}_{4}$. The values of the liquid junction potential, $E_{\mathrm{j}}$, for the phosphate buffer and the buffer solutions were obtained using the flowing junction method [8]. The $\delta E_{\mathrm{j}}$ values of the standard buffer solution for cell (B) were calculated using the following equation:

$\delta E_{\mathrm{j}}=E+E_{S C E}^{\circ}-k \mathrm{pH}$

where the values of $k=0.059156, \mathrm{pH}=7.415$ at $T=298.15$ $\mathrm{K} ; k=0.061538$ and $\mathrm{pH}=7.395$ at $T=310.15 \mathrm{~K}$ were obtained from the literature [12]. The $\mathrm{pH}(\mathrm{s})$ values are that of the standard phosphate buffer solution and the $\mathrm{pH}(\mathrm{x})$ for BICINE buffer solutions. The relationship between $\mathrm{pH}(\mathrm{x})$ and $\mathrm{pH}(\mathrm{s})$ is as follows:

$\mathrm{pH}(\mathrm{x})=\mathrm{pH}(\mathrm{s})+\frac{E_{x}-E_{s}+\delta E_{j}}{k}$.

To calculate the $\mathrm{pH}$ values for all buffer solutions under investigation, calculations were made to determine the acidity function, denoted as $\mathrm{p}\left(a_{\mathrm{H}} \gamma_{\mathrm{Cl}}\right)$, in the temperature range (278.15 to 328.15$) \mathrm{K}$. These calculations [10-13, 16-18] were made using the emf $(E)$ values listed in Tables $\mathbf{1}$ and $\mathbf{2}$, the molality of the chloride ion, and the standard electrode potential of the silver-silver chloride electrode $\left(E^{\circ}\right)$. The equation to calculate the quantity $\mathrm{p}\left(a_{\mathrm{H}} \gamma_{\mathrm{Cl}}\right)$ is shown below:

$p\left(a_{H} \gamma_{C l}\right)=\frac{E-E^{\circ}}{k}+\log m_{C l^{-}}$

where " $\mathrm{k}$ " is the Nernst slope.

When plotting $\mathrm{p}\left(a_{\mathrm{H}} \gamma_{\mathrm{Cl}}\right)$ vs. $m_{\mathrm{Cl}^{-}}$, linear line with a small slope was obtained to determine the intercept on the y-axis to give a $\mathrm{p}\left(a_{\mathrm{H}} \gamma_{\mathrm{Cl}}\right)^{\circ}$ value at $m_{\mathrm{Cl}}=0$. These $\mathrm{p}\left(a_{\mathrm{H}} \gamma_{\mathrm{Cl}}\right)^{\circ}$ values for the chloride-free buffer solutions are listed in Table 3. The $\mathrm{p}\left(a_{\mathrm{H}} \gamma_{\mathrm{Cl}}\right)$ values for the buffer solutions containing $\mathrm{Cl}^{-}$are entered in Table 4 from (278.15 to 328.15) K.

The $\mathrm{pH}(\mathrm{s})$ values for solutions without liquid junction in the absence of $\mathrm{NaCl}$ were determined using the following equation:

$p H(s)=p\left(a_{H} \gamma_{C l}\right)^{\circ}+\log \gamma_{C l}^{0}$

where the single-ion activity coefficient, $\gamma_{C l}^{0}$, cannot be experimentally measured. For the calculation of $\gamma_{C l}^{\circ}$, the " $\mathrm{pH}$ convention" commonly known as the Bates-Guggenheim convention [5], is expressed by the equation:

$\log \gamma_{C l}^{\circ}=-\frac{A \sqrt{I}}{1+1.5 \sqrt{I}}$

The International Union of Pure and Applied Chemistry, IUPAC, has recommended the use of this convention, but Eq. 5 is assumed to be valid for systems where $I$ is no more than $0.1 \mathrm{~mol} \cdot \mathrm{kg}^{-1}$. For $I$ greater than $0.1 \mathrm{~mol} \cdot \mathrm{kg}^{-1}$, there is no single widely accepted convention. A superior choice for solutions with $I$ greater than $0.1 \mathrm{~mol} \cdot \mathrm{kg}^{-1}$ may need to include a linear-dependent " $C F$ " term shown in Eq. 6 with an ion size parameter as well as be temperature dependent.

An extended Debye-Hückel equation [7, 9] has been selected to be the more logical approach to calculate $\log \gamma_{C l}^{0}$ when $I$ is greater than $0.1 \mathrm{~mol} \cdot \mathrm{kg}^{-1}$ for all of the buffer solutions containing $\mathrm{Cl}^{-}$.

$$
\log \gamma_{C l}^{\circ}=-\frac{A \sqrt{I}}{1+B a^{\circ} \sqrt{I}}+C I
$$

where " $I$ " is the ionic strength of the buffer solution, " $A$ " and " $B$ " are slope parameters known as the Debye-Hückel constants, and " $C$ " is an adjustable parameter defined by Eq. 7. The following empirical equation is used for the calculation of the adjustable parameter " $C$ " and was obtained from a curve-fitting method [7,9]:

$C=C_{298.15}+\left(6.210^{-4}\right)(T-298.15)-\left(8.7 \cdot 10^{-6}\right)(T-298.15)^{2}$

where $\mathrm{C}_{298.15}=0.032 \mathrm{~kg} \cdot \mathrm{mol}^{-1}$ at $298.15 \mathrm{~K}$ and " $T$ " is the temperature in Kelvin. 
Table 3. $\quad p\left(a_{\mathrm{H}} \gamma_{\mathrm{Cl}}\right)^{\circ}$ of (BICINE+ NaBICINE) Buffer Solutions from (278.15 to 328.15) K, Obtained by Extrapolation for ChlorideFree Solutions ${ }^{\text {a }}$ Using Eq. 3

\begin{tabular}{|c|c|c|c|}
\hline \multirow[b]{3}{*}{$T / \mathbf{K}$} & $0.02 m$ BICINE & 0.04 $m$ BICINE & 0.06 $m$ BICINE \\
\hline & \multicolumn{3}{|c|}{$+0.04 \mathrm{mNaBICINE}+0.08 \mathrm{mNaBICINE}+0.06 \mathrm{mNaBICINE}$} \\
\hline & $I=0.04 \mathrm{~m}$ & $I=0.08 \mathrm{~m}$ & $I=0.06 \mathrm{~m}$ \\
\hline 278.15 & 8.627 & 8.568 & 8.442 \\
\hline 283.15 & 8.533 & 8.476 & 8.356 \\
\hline 288.15 & 8.439 & 8.386 & 8.271 \\
\hline 293.15 & 8.353 & 8.297 & 8.190 \\
\hline 298.15 & 8.270 & 8.216 & 8.111 \\
\hline 303.15 & 8.191 & 8.137 & 8.034 \\
\hline 308.15 & 8.116 & 8.057 & 7.958 \\
\hline 310.15 & 8.089 & 8.024 & 7.926 \\
\hline 313.15 & 8.052 & 7.979 & 7.883 \\
\hline 318.15 & 7.985 & 7.905 & 7.810 \\
\hline 323.15 & 7.926 & 7.833 & 7.735 \\
\hline 328.15 & 7.868 & 7.758 & 7.664 \\
\hline
\end{tabular}

${ }^{\mathrm{a}} m=1 \mathrm{~mol} \cdot \mathrm{kg}^{-1}$

Table 4. $\quad p\left(a_{\mathrm{H}} \gamma_{\mathrm{Cl}}\right)$ of (BICINE+ NaBICINE) Buffer Solutions from 5 to $55^{\circ} \mathrm{C}$, Computed Using Eq. 4

\begin{tabular}{|c|c|c|c|c|c|c|c|c|c|c|c|c|c|c|}
\hline$m_{1}$ & $m_{2}$ & $m_{3}$ & \multicolumn{12}{|c|}{$T / K$} \\
\hline \multicolumn{3}{|c|}{$\mathrm{mol} \cdot \mathrm{kg}^{-1}$} & 278.15 & 283.15 & K 288.15 & 293.15 & 298.15 & 303.15 & 308.15 & 310.15 & 313.15 & 318.15 & 323.15 & 328.15 \\
\hline 0.02 & 0.02 & 0.14 & 8.458 & 8.375 & 8.292 & 8.206 & 8.125 & 8.049 & 7.973 & 7.942 & 7.902 & 7.831 & 7.763 & 7.697 \\
\hline 0.04 & 0.04 & 0.12 & 8.446 & 8.362 & 8.278 & 8.195 & 8.114 & 8.038 & 7.961 & 7.931 & 7.889 & 7.820 & 7.753 & 7.687 \\
\hline 0.05 & 0.05 & 0.11 & 8.441 & 8.354 & 8.268 & 8.185 & 8.106 & 8.030 & 7.953 & 7.924 & 7.881 & 7.813 & 7.746 & 7.679 \\
\hline 0.06 & 0.06 & 0.10 & 8.436 & 8.347 & 8.261 & 8.178 & 8.101 & 8.025 & 7.948 & 7.919 & 7.875 & 7.807 & 7.741 & 7.674 \\
\hline 0.09 & 0.03 & 0.13 & 8.171 & 8.083 & 7.997 & 7.915 & 7.831 & 7.752 & 7.674 & 7.640 & 7.600 & 7.530 & 7.460 & 7.394 \\
\hline
\end{tabular}

The $\mathrm{pH}(\mathrm{s})$ values listed in Table $\mathbf{5}$ for the BICINE buffer solutions without the presence of $\mathrm{Cl}^{-}$were calculated using the following equations with their respective solution compositions:

BICINE (0.02) + NaBICINE (0.02): $\mathrm{pH}(\mathrm{s})=8.191+\left(1.62 \cdot 10^{-2}\right)(T-298.15)-\left(9.0 \cdot 10^{-5}\right)(T-$ $298.15)^{2}$

BICINE (0.04) + NaBICINE (0.08): $\mathrm{pH}(\mathrm{s})=8.116+\left(1.67 \cdot 10^{-2}\right)(T-298.15)-\left(4.3 \cdot 10^{-5}\right)(T-$ $298.15)^{2}$

BICINE (0.06) + NaBICINE (0.06):

$\mathrm{pH}(\mathrm{s})=8.020+\left(1.59 \cdot 10^{-2}\right)(T-298.15)-\left(3.0 \cdot 10^{-5}\right)(T-$ $298.15)^{2}$

for the temperature range of (278.15 to 328.15$) \mathrm{K}$. The standard deviations of regression for the $\mathrm{pH}(\mathrm{s})$ of the chloride- free buffer solutions are $0.0017,0.0020$, and 0.0013 , respectively.

For the buffer solutions containing $\mathrm{NaCl}$, with an isotonic saline media ionic strength of $I=0.16 \mathrm{~mol} \cdot \mathrm{kg}^{-1}$, the $\mathrm{pH}(\mathrm{s})$ values were also calculated using Eqs. 3 to 7.The acidity function data $\mathrm{p}\left(a_{\mathrm{H}} \gamma_{\mathrm{Cl}}\right)$ for buffer solutions containing $\mathrm{NaCl}$ are listed in Table 4. The values of the $\mathrm{pH}(\mathrm{s})$ for these solutions entered in Table $\mathbf{6}$ are expressed by use of the following equations:

BICINE (0.02) + NaBICINE (0.02) $+\mathrm{NaCl}(0.14)$ : $\mathrm{pH}(\mathrm{s})=8.000-\left(1.59 \cdot 10^{-2}\right)(T-298.15)-\left(4.60 \cdot 10^{-5}\right)(T-$ $298.15)^{2}$

BICINE (0.04) + NaBICINE (0.04) + $\mathrm{NaCl}(0.12)$ : $\mathrm{pH}(\mathrm{s})=7.988-\left(1.58 \cdot 10^{-2}\right)(T-298.15)-\left(4.59 \cdot 10^{-5}\right)(T-$ $298.15)^{2}$

BICINE (0.05) + NaBICINE (0.05) + $\mathrm{NaCl}(0.11)$ : 
Table 5. pH(s) of (BICINE + NaBICINE)Buffer Solutions from (278.15 to 328.15) K, Computed Using Eqs. 4, 5, 6, $7^{\mathrm{a}}$

\begin{tabular}{|c|c|c|c|}
\hline & $0.02 \mathrm{~m}$ BICINE & $0.04 \mathrm{~m}$ BICINE & $0.06 \mathrm{~m}$ BICINE \\
\hline & + $0.04 \mathrm{mNaBICINE}$ & $+0.08 \mathrm{mNaBICINE}$ & $+0.06 \mathrm{mNaBICINE}$ \\
\hline $\mathbf{T} / \mathbf{K}$ & $\mathrm{I}=\mathbf{0 . 0 4} \mathrm{m}$ & $\mathrm{I}=0.08 \mathrm{~m}$ & $\mathrm{I}=0.06 \mathrm{~m}$ \\
\hline 278.15 & 8.557 & 8.468 & 8.352 \\
\hline 283.15 & 8.464 & 8.376 & 8.266 \\
\hline 288.15 & 8.369 & 8.286 & 8.181 \\
\hline 293.15 & 8.284 & 8.197 & 8.100 \\
\hline 298.15 & 8.201 & 8.114 & 8.020 \\
\hline 303.15 & 8.121 & 8.035 & 7.942 \\
\hline 308.15 & 8.048 & 7.955 & 7.865 \\
\hline 310.15 & 8.022 & 7.922 & 7.833 \\
\hline 313.15 & 7.983 & 7.876 & 7.790 \\
\hline 318.15 & 7.915 & 7.802 & 7.715 \\
\hline 323.15 & 7.853 & 7.728 & 7.640 \\
\hline 328.15 & 7.792 & 7.652 & 7.568 \\
\hline
\end{tabular}

Table 6. $\quad$ pH(s) of (BICINE + NaBICINE)Buffer Solutions from (278.15 to 328.15) K,Computed Using Eqs. 4, 5, 6,7

\begin{tabular}{|c|c|c|c|c|c|c|c|c|c|c|c|c|c|c|}
\hline$m_{1}$ & $\boldsymbol{m}_{2}$ & $m_{3}$ & \multicolumn{12}{|c|}{$T / K$} \\
\hline 0.02 & 0.02 & 0.14 & 8.333 & 8.250 & 8.166 & 8.081 & 7.998 & 7.922 & 7.845 & 7.815 & 7.773 & 7.702 & 7.633 & 7.566 \\
\hline 0.04 & 0.04 & 0.12 & 8.320 & 8.236 & 8.152 & 8.070 & 7.987 & 7.911 & 7.833 & 7.803 & 7.760 & 7.691 & 7.623 & 7.555 \\
\hline 0.05 & 0.05 & 0.11 & 8.315 & 8.228 & 8.143 & 8.060 & 7.980 & 7.903 & 7.826 & 7.796 & 7.753 & 7.683 & 7.616 & 7.548 \\
\hline 0.09 & 0.03 & 0.13 & 8.046 & 7.957 & 7.872 & 7.790 & 7.705 & 7.625 & 7.547 & 7.518 & 7.472 & 7.401 & 7.330 & 7.262 \\
\hline
\end{tabular}

$\mathrm{pH}(\mathrm{s})=7.980-\left(1.58 \cdot 10^{-2}\right)(T-298.15)-\left(4.85 \cdot 10^{-5}\right)(T-$ $298.15)^{2}$

BICINE (0.06) + NaBICINE (0.06) + $\mathrm{NaCl}(0.10)$ : $\mathrm{pH}(\mathrm{s})=7.974-\left(1.58 \cdot 10^{-2}\right)(T-298.15)-\left(4.93 \cdot 10^{-5}\right)(T-$ $298.15)^{2}$

BICINE (0.09) + NaBICINE (0.03) + $\mathrm{NaCl}(0.13)$ : $\mathrm{pH}(\mathrm{s})=7.705-\left(1.61 \cdot 10^{-2}\right)(T-298.15)-\left(4.59 \cdot 10^{-5}\right)(T-$ 298.15) $)^{2}$

The observed standard deviations of regression from Eqs.11 -15 are $0.0018,0.0013,0.0008,0.0013$, and 0.0012 , respectively.

\section{CONCLUSIONS}

The emf values of cells (B) and (C) at (298.15 and $310.15) \mathrm{K}$ are given in Table 7. The operational $\mathrm{pH}$ values at these two temperatures were evaluated from cells (B) and (C) by means of the flowing junction cell [7,9]. The values of $\delta E_{\mathrm{j}}$ were obtained using Eq. 1and are also listed in Table 7. The summation of the standard uncertainties for the $\mathrm{pH}(\mathrm{s})$ values was accounted for by combining multiple known sources of error: (i) values of $\mathrm{p}\left(a_{\mathrm{H}} \gamma_{\mathrm{Cl}}\right)^{\circ}$ for $\mathrm{Cl}^{-}$free solutions are within $\pm 0.001 \mathrm{pH}$ unit, (ii) assumption for the calculation of $\log \gamma_{\mathrm{Cl}}^{\mathrm{o}}$ using Eq.6 leads to an error of $\pm 0.002 \mathrm{pH}$ unit; (iii) emf measurement is within $\pm 0.001 \mathrm{pH}$ unit, and (iv) estimation of $\delta E_{\mathrm{j}}$ values yield an error of $0.003 \mathrm{pH}$ unit. Thus, the overall error is $\pm 0.007 \mathrm{pH}$ unit for buffer solutions with and without the presence of $\mathrm{Cl}^{-}$, respectively. For BICINE, $m_{1}=0.04, m_{2}=0.04$, and $m_{3}=0.12$; excellent agreement between the calculated values with the use of the extended Debye-Hückel equation and values with the liquid junction correction at $310 \mathrm{~K}$ is 7.803 and 7.803 , respectively. Two buffer solutions of BICINE have $\mathrm{pH}$ values in the narrow range 7.7 to 8.0 and are recommended as useful primary $\mathrm{pH}$ standards for calibrating glass electrodes of the $\mathrm{pH}$ meter. The authors are working for the determination of $\mathrm{pH}$ values of various buffer solutions using Pitzer ionic interaction the- 
Table 7. Emf of Cell B and $\mathrm{pH}$ Values with $\delta$ EjCorrection at (298.15 and 310.15) $\mathrm{K}$ for BICINE Buffer

\begin{tabular}{|c|c|c|c|c|c|c|c|c|c|c|c|c|c|}
\hline \multirow[t]{2}{*}{$\mathbf{m}_{1}$} & \multirow[t]{2}{*}{$\mathbf{m}_{2}$} & \multirow[t]{2}{*}{$\mathbf{m}_{3}$} & \multirow[t]{2}{*}{ I } & \multicolumn{2}{|c|}{$\mathbf{E} / \mathbf{V}$} & \multicolumn{2}{|c|}{$\delta E_{j}^{b} / m V$} & \multirow{2}{*}{$\begin{array}{c}\text { With- } \\
\text { out }^{\mathrm{c}} \\
\delta \mathbf{E}_{\mathrm{j}} \text { corr }\end{array}$} & \multirow{2}{*}{\multicolumn{2}{|c|}{$\begin{array}{c}\text { With }^{\mathrm{d}} \\
\delta \mathrm{E}- \\
\mathrm{j} \operatorname{corr} \\
298.15 \mathrm{~K}\end{array}$}} & \multirow{2}{*}{\multicolumn{2}{|c|}{\begin{tabular}{c|c} 
Without $^{\mathrm{c}}$ & With $^{\mathrm{d}}$ \\
$\delta \mathrm{E}_{\mathrm{j}} \operatorname{corr}$ & $\begin{array}{c}\delta \mathrm{E}- \\
\mathrm{j} \operatorname{corr}\end{array}$ \\
& $310.15 \mathrm{~K}$
\end{tabular}}} & \multirow{2}{*}{$\begin{array}{c}\text { Extend- } \\
\text { ed }^{\mathrm{e}} D-H \\
\text { eqn. }\end{array}$} \\
\hline & & & & $\begin{array}{c}298.15 \\
K\end{array}$ & $\begin{array}{c}310.15 \\
K\end{array}$ & $\begin{array}{c}298.15 \\
\text { K }\end{array}$ & $\begin{array}{c}310.15 \\
\text { K }\end{array}$ & & & & & & \\
\hline 0.04 & 0.04 & 0.12 & 0.16 & 0.68180 & 0.67861 & 2.2 & 2.3 & 7.949 & 7.986 & 7.987 & 7.766 & 7.803 & 7.803 \\
\hline 0.05 & 0.05 & 0.11 & 0.16 & 0.68926 & 0.68591 & 2.2 & 2.3 & 7.944 & 7.980 & 7.980 & 7.760 & 7.795 & 7.796 \\
\hline \multicolumn{14}{|c|}{ Emf of Cell C $C^{a}$} \\
\hline \multicolumn{2}{|c|}{$\begin{array}{c}0.008695 \mathrm{~m} \mathrm{KH}_{2} \mathrm{PO}_{4}+ \\
0.03043 \mathrm{~m} \mathrm{Na}_{2} \mathrm{HPO}_{4}\end{array}$} & 0.68275 & 0.69147 & 2.6 & 2.9 & & & & & & & & \\
\hline
\end{tabular}

${ }^{\mathrm{a}}$ Corrected to a hydrogen pressure of $101.325 \mathrm{kPa}$ for physiological phosphate buffer solutions (primary reference standard buffer) at (298.15 and 310.15 ) $\mathrm{K}$ [7].

${ }^{\mathrm{b}} \delta E_{\mathrm{j}}=E+E_{S C E}^{\circ}-k \mathrm{pH}$ from Eq. 1 is the Emf from Table 7, $k=$ Nernst slope with values 0.059156 at $T=298.15 \mathrm{~K}$, and 0.061538 at $T=310.15 \mathrm{~K}$; the $\mathrm{pH}$ of the primary reference standard phosphate buffer is 7.415 and 7.395 at $(298.15$ and 310.15$) \mathrm{K}$, respectively; $E_{S C E}^{\circ}=$ electrode potential of the saturated calomel electrode $=-0.2415$ and -0.2335 at $(298.15$ and 310.15$) \mathrm{K}[14,15]$, respectively; units of $m, \mathrm{~mol}^{-\mathrm{kg}^{-1}}$.

${ }^{\mathrm{c}}$ Values obtained from Eq. 2 where $\delta E_{\mathrm{j}}=0$ and Table 7

${ }^{\mathrm{d}}$ Obtained from Eq. 2 and Table 7

${ }^{\mathrm{e}}$ Obtained from extended Debye-Hückel (DH) equation of the Bates-Guggenheim convention

ory [19-20] for the calculation of the single ion activity coefficient, $\gamma_{\mathrm{Cl}}$.

\section{CONFLICTS OF INTEREST}

The authors confirm that this article content has no conflicts of interest.

\section{ACKNOWLEDGEMENTS}

The authors are grateful for the funding from the National Institutes of Health (AREA), under the grant 2-R15 GM 066866-03 and the diversity supplemental grant 3-R15 GM 066866-03 S1. The authors would also like to thank Samantha Rose and Austin Seaborn for their dedicated and hard work. The content of this paper is the sole responsibility of the authors and does not necessarily represent the official views of the National Institutes of Health or the National Institutes of General Medical Sciences.

\section{DISCLOSURE}

Part of the information included in this article has been previously published from the work done in the author's lab in J. Chem. Eng. Data, 2009, 54 (6), pp 1860-1864.

\section{REFERENCES}

[1] Good, N. E.; Winget, G. D.; Winter, W.; Connolly, T. N.; Izawa, S.; Singh, R. M. M. Hydrogen ion buffers for biological research. Biochemistry., 1966, 5, 467-477.

[2] Ferguson, W. J.; Braunschweiger, K. I.; Braunschweiger, W. R.; Smith, J. R.; McCormick, J. J.; Wasmann, C. C.; Jarvis, N. P.; Bell, D. H.; Good, N. E. Hydrogen ion buffers for biological research. Anal. Biochem., 1980, 104, 300 -310.

[3] Roy, L. N.; Roy, R. N.; Denton, C. E.; LeNoue, S. R.; Roy, C. N.; Ashkenazi, S.; Williams, T. B.; Church, D. R.; Fuge, M. S.; Sreepada, K. S. Second dissociation constant of bis-[(2hydroxyethyl)amino]acetic acid (BICINE) and $\mathrm{pH}$ of its buffer solutions from $5-55^{\circ}$ C. J. Solution Chem., 2006, 35, 605-624.
[4] Roy, L. N.; Roy, R. N.; Allen, K. A.; Mehrhoff, C. J.; Henson, I. B.; Stegner, J. M.; Downs, Z. M. Buffer standards for the physiological $\mathrm{pH}$ of $N$-(2-hydroxyethyl)piperazine- $N$ '-4-butanesulfonic acid (HEPBS) from 5 to $55^{\circ} \mathrm{C}$. The Open Electrochemistry Journal., 2012, 4, 13-19.

[5] Bower, V. E.; Paabo, M.; Bates, R. G. A standard for the measurement of the $\mathrm{pH}$ of blood and other physiological media. J. Res. Natl. Bur. Stand., 1961, 65A, 267-270.

[6] Durst, R. A.; Staples, B. R. Tris/Tris HC1: Standard buffer for use in the physiological pH range. Clin. Chem., 1972, 18, 206-208.

[7] Feng, D.; Koch, W. F.; Wu, Y. C. Second dissociation constant and $\mathrm{pH}$ of $N$-(2-hydroxyethyl)piperazine- $N$ '-2-ethanesulfonic acid from 0 to $50^{\circ} \mathrm{C}$. Anal. Chem., 1989, 61, 1400-1405.

[8] Wu, Y. C., Berezansky, P. A., Feng, D., Koch, W. F. Second dissociation constant of 3-( $N$-morpholino)-2-hydroxypropanesulfonic acid and $\mathrm{pH}$ of its buffer solutions. Anal. Chem., 1993, 65, 10841087.

[9] Roy, L. N.; Roy, R. N.; LeNoue, S. R.; Denton, C. E.; Fuge, M. S.; Dunseth, C. D.; Roy, C. N.; Hayden, S. R.; Wollen, J. T.; Sreepada, $\mathrm{K}$. Buffer standards for the physiological $\mathrm{pH}$ of the zwitterionic compound, DIPSO from 5 to $55^{\circ}$ C. J. Solution Chem., 2009, 38, 459-469.

[10] Bates, R. G., Vega, C. A., White, D. R. Jr. Standards for pH measurements in isotonic saline media of ionic strength $I=0.16$. Anal. Chem., 1978, 50, 1295-1300.

[11] Bates, R. G. Determination of $p H, 3^{\text {rd }}$ ed.; Wiley: New York, 1973.

[12] Roy, R. N.; Roy, L. N.; Denton, C. E.; LeNoue, S. R.; Ashkenazi, S.; Fuge, M. S.; Dunseth, C. D.; Durden, J. L.; Roy, C. N.; Bwashi, A.; Wollen, J. T.; DeArmon, S. J. Buffer standards for the physiological $\mathrm{pH}$ of 3-[(1,1-dimethyl-2-hydroxymethyl)amino]-2hydroxypropanesulfonic acid (AMPSO) from (278.15 to 328.15$) \mathrm{K}$. J. Chem. Eng. Data, 2009, 54, 425- 435.

[13] Roy, L. N.; Roy, R. N.; Denton, C. E.; LeNoue, S. R.; Roy, C. N.; Ashkenazi, S.; Williams, T. B.; Church, D. R.; Fuge, M. S.; Sreepada, K. S. Second dissociation constant of bis-[(2hydroxyethyl)amino]acetic acid (BICINE) and $\mathrm{pH}$ of its buffer solutions from 5 - $55^{\circ}$ C. J. Solution Chem., 2006, 35, 605-624.

[14] Roy, R. N.; Roy, L. N.; Ashkenazi, S.; Wollen, J. T.; Dunseth, C. D.; Fuge, M. S.; Roy, C. N.; Hughes, H. M.; Morris, B. T.; Cline, K. L. Buffer standards for $\mathrm{pH}$ measurement of $\mathrm{N}-(2-$ hydroxyethyl)piperazine-N'-2-ethanesulfonic acid (HEPES) for $I=0.16 \mathrm{~mol} \cdot \mathrm{kg}^{-1}$ from 5 to $55^{\circ}$ C. J. Solution Chem., 2009, 38, 449458.

[15] Latimer, W. M. Oxidation Potentials, $2^{\text {nd }}$ ed.; Prentice-Hall: New York, 1952. 
[16] Vega, C. A.; Bates, R. G.Buffers for the physiological $\mathrm{pH}$ range: Thermodynamic constants of four substituted aminoethanesulfonic acids from 5 to $50^{\circ} \mathrm{C}$. Anal. Chem., 1976, 48, 1293-1296.

[17] Bates, R. G., Roy, R. N., Robinson, R. A. Buffer standards of tris(hydroxymethyl) methylglycine ("Tricine") for the physiological range $\mathrm{pH} 7.2$ to 8.5. Anal. Chem., 1973, 45, 1663-1666.

[18] Bates, R. G., Guggenheim, E. A. Report on the standardization of $\mathrm{pH}$ and related terminology. Pure Appl. Chem., 1960, 1, 163-168.
[19] Pitzer, K. S., Mayorga, G. J. Thermodynamics of electrolytes. II. Activity and osmotic coefficients for strong electrolytes with one or both ions univalent. J. Phys. Chem., 1973, 77, 2300-2310.

[20] Covington, A. K., Ferra, M. I. A. A Pitzer mixed electrolyte solution theory approach to assignment of $\mathrm{pH}$ to standard buffer solutions. J. Solution Chem., 1994, 23, 1-10.

(C) Roy et al.; Licensee Bentham Open

This is an open access article licensed under the terms of the Creative Commons Attribution Non-Commercial License (http://creativecommons.org/licenses/by-nc/3.0/) which permits unrestricted, non-commercial use, distribution and reproduction in any medium, provided the work is properly cited. 